\title{
PEMBELAJARAN DARING YANG INTERAKTIF DI ERA NEW NORMAL
}

\author{
Nihayatus Sa'adah \\ Program Studi Pendidikan Matematika, Universitas Hasyim Asy’ari Jombang \\ nihayahsyakir@gmail.com
}

\begin{abstract}
COVID-19 outbreak had changed the order of social life in Indonesia. As school is shutting down, many teachers face the hardship to observe the students' activity. Many students seen active by online but they didn't give their best effort to join the learning process. One way could be used to overcome this problem is by conducting the interactive learning process that enabled the realtime interaction between teacher and students. This community service activity was held in SMP Al Furqan MQ located in Tebuireng that involving 33 participants. The used method was lecturing dan direct implementation. This training enhanced the participants' information and insight so it could be used in online learning process.
\end{abstract}

Keywords: Online learning process, interactive learning process

\begin{abstract}
Abstrak: Wabah COVID-19 banyak mengubah tatanan kehidupan bermasyarakat di Indonesia. Dengan ditiadakannya cara tatap muka dalam sistem pembelajaran di sekolah, guru memiliki kesulitan untuk memantau aktivitas siswa. Sering terjadi siswa aktif secara maya namun pada kenyataannya siswa tidak mengikuti proses pembelajaran. Salah satu cara yang bisa digunakan untuk mengatasi masalah tersebut adalah dengan mengadakan pembelajaran daring yang memungkinkan adanya interaksi antara guru dan siswa. Pelaksanaan kegiatan Pengabdian kepada Masyarakat ini dilakukan di SMP Al Furqan MQ Tebuireng dengan total 33 peserta. Metode yang digunakan adalah pelatihan dan praktik. Pelatihan ini dapat menambah informasi dan wawasan guru yang nantinya bisa dipakai dalam pembelajaran daring di sekolah ini.
\end{abstract}

Kata Kunci: Pembelajaran Daring, Pembelajaran Interaktif

\section{Pendahuluan}

Akhir tahun 2019 dunia dikagetkan dengan adanya berita wabah baru yang terjadi di Tiongkok. Wabah penyakit yang dinamakan COVID-19 (Corona Virus Desease-19) ini disebabkan oleh suatu virus yang disebut Covid-SARS-2. Sampai akhirnya pada awal Maret 2020 wabah ini masuk juga di Indonesia (Ihsanuddin, 2020). Dimulai dari dua orang yang berdomisili di Depok, Jawa Barat, kemudian menyebar sampai ke seluruh Indonesia. Istilah masa new normal digunakan untuk mengacu pada waktu tiga bulan setelah COVID-19 masuk di Indonesia atau Juni 2020.

Wabah COVID-19 ini selanjutnya mengubah banyak sistem kehidupan bermasyarakat di Indonesia, termasuk sistem pendidikan. Pemerintah melalui Kementerian Pendidikan dan Kebudayaan telah menerbitkan Surat Edaran Nomor 4 Tahun 2020 tentang Pelaksanaan Kebijakan Pendidikan dalam Masa Darurat Penyebaran
COVID-19. Sekolah-sekolah ditutup dan pembelajaran diubah menjadi sistem daring (online). Guru dan siswa yang biasanya berkumpul dalam satu ruangan dan berinteraksi secara langsung akhirnya harus beradaptasi dengan sistem baru. Menurut Mustofa, Chodzirin, dan Sayekti (2019), perkuliahan (pembelajaran) daring adalah metode pembelajaran online atau dilakukan melalui jaringan internet. Pembelajaran daring yang amat bergantung pada gawai (gadget) dan koneksi internet ini membuat guru dan siswa bisa melakukan pembelajaran secara terpisah ruang.

Akan tetapi, terpisahnya ruang ini memunculkan satu masalah baru. Sistem pembelajaran daring yang tidak menggunakan video realtime membuat siswa bisa saja aktif secara maya namun tidak aktif secara nyata dalam proses pembelajaran. Sebaliknya, sistem pembelajaran daring yang menggunakan video realtime membutuhkan 
kuota internet yang begitu besar dan tidak semua siswa bisa memenuhinya.

\section{Metode}

Kegiatan Pengabdian kepada Masyarakat yang berupa pelatihan ini dilakukan di SMP Al Furqan Madrasatul Qur'an Tebuireng pada tanggal 15 - 16 Juli 2020. Peserta kegiatan ini adalah 33 orang guru dari berbagai macam mata pelajaran yang nantinya akan mengajar secara daring di sekolah tersebut. Metode yang diterapkan dalam kegiatan ini adalah pelatihan dan praktek langsung. Kegiatan Pengabdian kepada Masyarakat ini melibatkan satu dosen sebagai narasumber dan satu mahasiswa sebagai asisten.

Kegiatan pada hari pertama: peserta berperan sebagai siswa yang mengikuti pembelajaran daring dengan narasumber sebagai gurunya. Selanjutnya, narasumber memberikan tugas untuk menyiapkan slide yang berisi materi dan pertanyaan serta sesuai dengan mata pelajaran yang diampu masing-masing.

Kegiatan pada hari kedua: peserta kegiatan diajari cara menyisipkan fitur-fitur interaktif pada slide yang sudah dibuat. Fiturfitur yang ada disajikan pada Tabel 1 di bawah ini.

Tabel 1. Fitur-Fitur yang Dapat Dipakai Guru untuk Berinteraksi dengan Siswa

\begin{tabular}{|l|l|}
\hline Fitur & \multicolumn{1}{|c|}{ Penjelasan } \\
\hline Template & $\begin{array}{l}\text { Tampilan slide yang bisa langsung } \\
\text { dipakai guru. Terdapat tiga macam } \\
\text { template: awal pelajaran, saat } \\
\text { pelajaran sedang berlangsung, akhir } \\
\text { pelajaran. }\end{array}$ \\
\hline Text & $\begin{array}{l}\text { Pilihan respon dari siswa yang } \\
\text { berupa teks panjang. }\end{array}$ \\
\hline Choice & $\begin{array}{l}\text { Pilihan respon dari siswa yang } \\
\text { berupa pilihan ganda. }\end{array}$ \\
\hline Number & $\begin{array}{l}\text { Pilihan respon dari siswa yang } \\
\text { berupa bilangan. }\end{array}$ \\
\hline Website & $\begin{array}{l}\text { Sumber berlajar berupa autan } \\
\text { terhadap website tertentu yang } \\
\text { disiapkan guru tanpa meninggalkan } \\
\text { tampilan slide. }\end{array}$ \\
\hline Draw & $\begin{array}{l}\text { Pilihan respon dari siswa berupa } \\
\text { gambar atautulisan tangan. }\end{array}$ \\
\hline Draggable & $\begin{array}{l}\text { Pilihan respon dari siswa berupa } \\
\text { pergeseran ikon tertentu. }\end{array}$ \\
\hline Audio & Sumber belajar berupa suara \\
\hline
\end{tabular}

\begin{tabular}{|c|l|}
\hline Fitur & \multicolumn{1}{|c|}{ Penjelasan } \\
\hline & $\begin{array}{l}\text { rekaman guru atau file audio tertentu } \\
\text { yang bisa didengar siswa tanpa } \\
\text { meninggalkan tampilan slide. }\end{array}$ \\
\hline
\end{tabular}

\section{Hasil dan Pembahasan}

Salah satu cara yang bisa digunakan guru untuk tetap bisa memantau aktivitas siswa secara nyata dan juga tidak memberatkan siswa terkait kuota internet adalah dengan menyiapkan slide yang memungkinkan siswa melakukan tanya jawab secara langsung.

Narasumber meminta peserta membuka link yang sudah disiapkan oleh narasumber. Dalam link tersebut, peserta bisa memberikan respon terhadap perintah narasumber di slide yang dibaca peserta.

Gambar 1 di bawah ini merupakan tampilan slide yang berupa pertanyaan dari narasumber sedangkan Gambar 2 merupakan tampilan jawaban-jawaban peserta. Narasumber bertanya, apa yang peserta pikirkan ketika melihat narasumber di depan. Peserta bisa menjawab pertanyaan penulis dengan cara mengetikkan jawaban di tempat yang disediakan di slide tersebut. Fitur yang digunakan dalam slide ini dinamakan Text.

Gambar 3 di bawah ini merupakan tampilan slide yang berupa pertanyaan dari narasumber. Narasumber bertanya, jika ada kesempatan, peserta ingin pergi ke mana. Peserta bisa menjawab pertanyaan narasumber dengan cara menggeser tanda bintang yang ada di slide tersebut. Fitur yang digunakan dalam slide ini dinamakan Draggable.

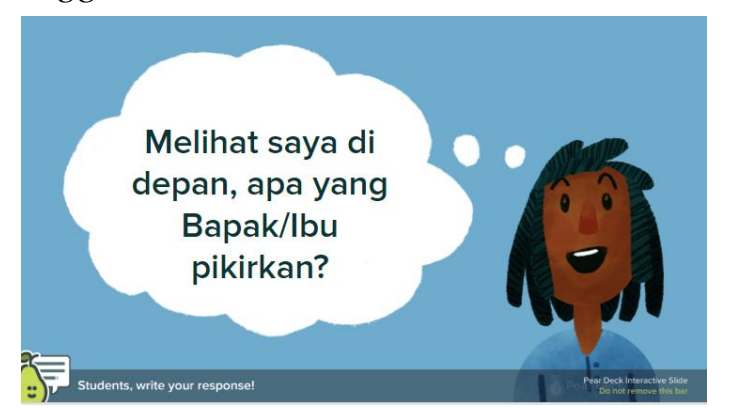

Gambar 1. Slide yang menampilkan pertanyaan dari narasumber 


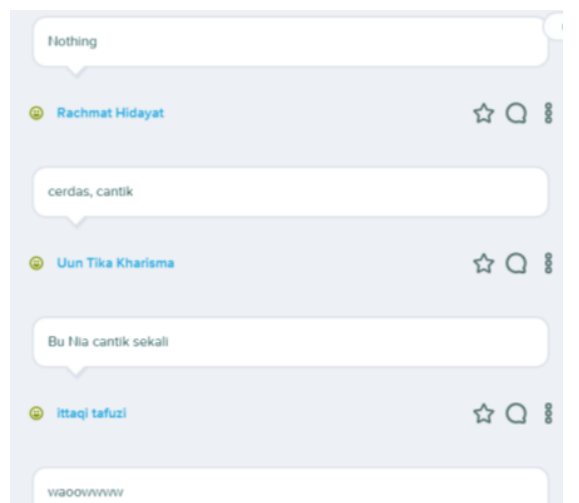

Gambar 2. Slide yang menampilkan jawabanjawaban peserta

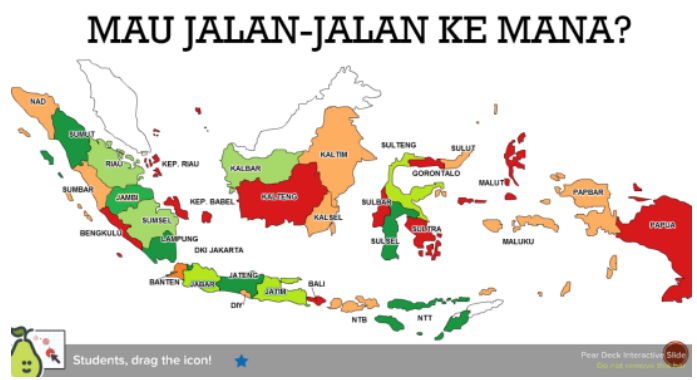

Gambar 3. Slide yang menampilkan pertanyaan dari guru

Dalam durasi waktu yang sudah ditentukan oleh narasumber, peserta bisa menggeser tanda bintang yang ada ke tempat yang ia inginkan untuk pergi ke sana. narasumber bisa mengecek jawaban peserta dalam dua cara: (1) jawaban semua peserta dalam satu slide (2) jawaban satu per satu peserta dalam masing-masing slide.

Gambar 4 di bawah ini merupakan tampilan slide yang menampilkan jawaban dari semua peserta. Terdapat 22 respon dari 33 peserta yang berpartisipasi di pelatihan kali ini. Kemungkinan besar sebelas peserta belum merespon karena kehabisan waktu. Narasumber bisa mengetahui peserta mana yang sudah memberikan respon dan mana yang belum seperti yang terpampang di Gambar 5 dan Gambar 6.
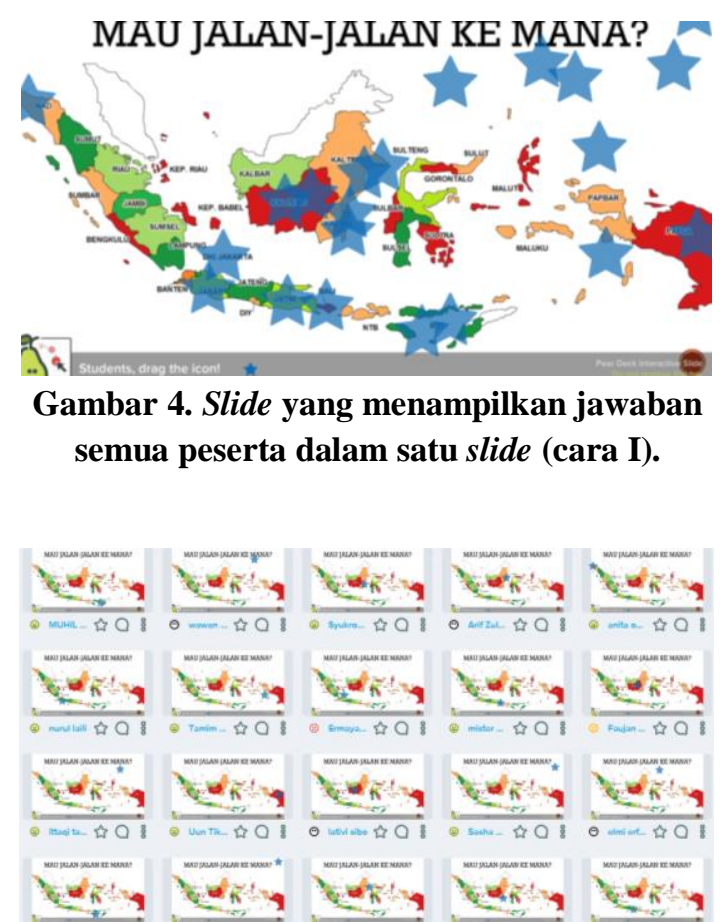

Gambar 5. Slide yang menampilkan jawaban masing-masing peserta (cara II).

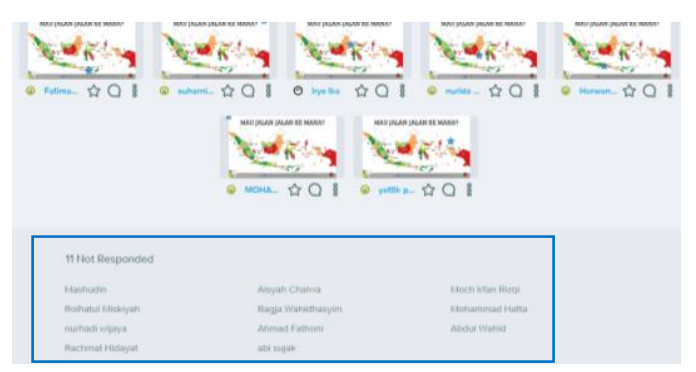

Gambar 6. Slide yang menampilkan nama

siswa yang belum memberikan respon.

Slide selanjutnya, narasumber bertanya apakah Bahasa Arabnya "saya minum". Tidak semua gawai memiliki fasilitas penulisan huruf Arab. Peserta bisa memilih akan menjawab pertanyaan narasumber dengan menggunakan keyboard jika gawainya tersedia fasilitas ini (Gambar 7) atau touchpad jika gawainya tidak menyediakan fasilitas huruf Arab (Gambar 8). Fitur yang digunakan dalam slide ini dinamakan Draw.

Fitur yang dipakai di slide selanjutnya adalah Choices. Narasumber bertanya kisah Nabi siapakah yang gambarnya terpampang di slide. Peserta bisa menjawab pertanyaan guru tersebut dengan mengeklik salah satu pilihan yang disediakan (Gambar 9). 


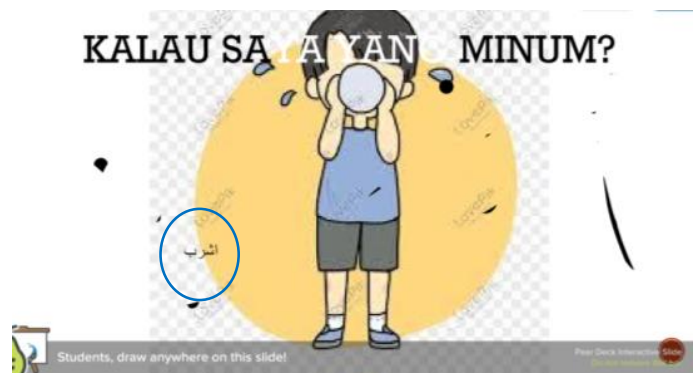

Gambar 7. Slide yang menampilkan jawaban peserta dalam huruf Arab menggunakan keyboard.

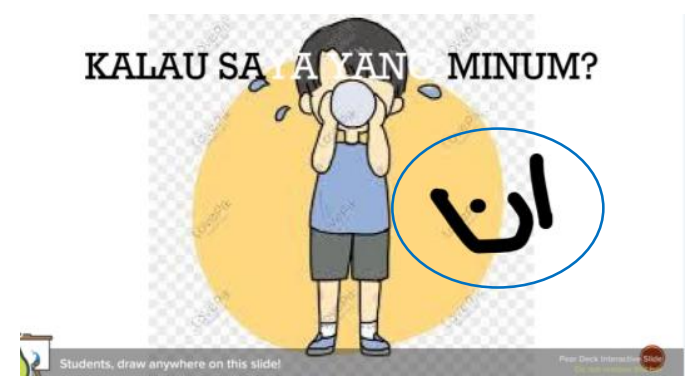

Gambar 8. Slide yang menampilkan jawaban peserta dalam huruf Arab menggunakan touchpad.

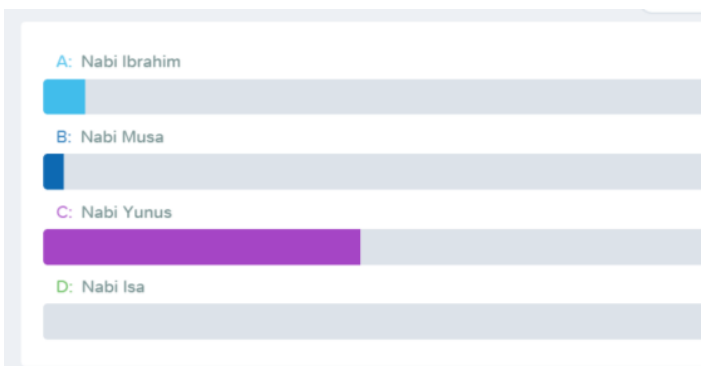

Gambar 9. Slide yang menampilkan jawaban peserta.

Fitur yang dipakai di slide selanjutnya adalah Number. Narasumber bertanya peserta merupakan anak keberapa. Peserta bisa menjawab pertanyaan guru tersebut dengan menuliskan angka yang merepresentasikan jawaban dari pertanyaan narasumber (Gambar 10 dan Gambar 11).

Sebagaimana yang terlihat pada Gambar 10, terdapat peserta yang memberikan repspon tidak sesuai dengan pertanyaan narasumber. Narasumber bisa memberikan umpan balik kepada peserta tersebut secara privat tanpa diketahui peserta lain dengan menggunakan fitur Leave Feedback (Gambar 12).

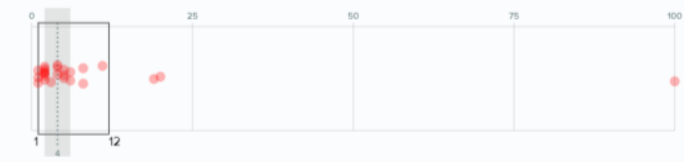

Gambar 10. Slide yang menampilkan jawaban semua peserta.

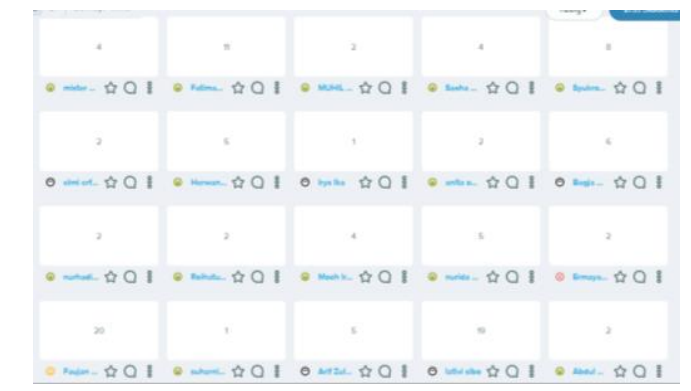

Gambar 11. Slide yang menampilkan jawaban masing-masing peserta.

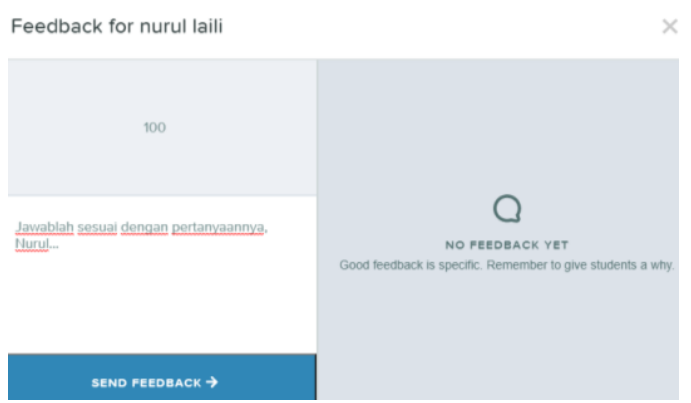

Gambar 12. Umpan balik untuk peserta yang menjawab pertanyaan dengan tidak serius.

\section{Simpulan}

Berdasarkan hasil dan pembahasan yang telah diuraikan sebelumnya dapat disimpulkan bahwa pelatihan ini memberikan informasi dan persepsi baru mengenai salah satu cara yang bisa dipakai untuk mengatasi masalah yang mungkin terjadi selama pembelajaran daring. Guru bisa menggunakan cara ini untuk memberikan materi secara daring dan sekaligus bisa memantau aktivitas siswa tanpa perlu merugikan siswa mengenai kuota internet. Selain itu, guru juga bisa langsung memberikan umpan balik pada siswa ketika dirasa ada siswa yang memberikan respon yang tidak sesuai dengan pertanyaan guru atau ada siswa yang mengganggu jalannya proses pembelajaran daring. 
40 | Nihayatus Sa'adah, dkk : Pembelajaran daring ...

\section{Daftar Pustaka}

Ihsanuddin. (2020, Juli 22). Breaking news: Jokowi umumkan dua orang di Indonesia positif Corona. Diakses dari: https://nasional.kompas.com/read/2020/0 3/02/11265921/breaking-news-jokowiumumkan-dua-orang-di-indonesiapositif-corona.

Kementerian Pendidikan dan Kebudayaan. (2020). Surat Edaran Nomor 4 Tahun 2020 tentang Pelaksanaan Kebijakan
Pendidikan dalam Masa Darurat COVID-19. Jakarta.

Mustofa, M.I., Chodzirin M., Sayekti, L. (2019). Formulasi Model Perkuliahan Daring sebagai Upaya Menekan Disparitas Kualitas Perguruan Tinggi (Studi terhadap Website pditt.belajar.kemdikbud.go.id). WJIT Walisongo Journal of Information Technology, 1(2), 151-160. 